\title{
A fate for organic acids, formaldehyde and methanol in cloud water: their biotransformation by micro-organisms
}

\author{
P. Amato ${ }^{1,2, *}$, F. Demeer ${ }^{1}$, A. Melaouhi ${ }^{1}$, S. Fontanella ${ }^{1}$, A.-S. Martin-Biesse ${ }^{1}$, M. Sancelme ${ }^{1}$, P. Laj $^{2}$, and \\ A.-M. Delort ${ }^{1}$ \\ ${ }^{1}$ Laboratoire de Synthèse et Etudes de Systèmes à Intérêt Biologique, UMR 6504 CNRS-Université Blaise Pascal, Aubière, \\ France \\ ${ }^{2}$ Laboratoire de Météorologie Physique, UMR 6016, CNRS-Université Blaise Pascal Aubière, France \\ *now at: Department of Biological Sciences, Louisiana State University, Baton Rouge, Louisiana, USA
}

Received: 19 March 2007 - Published in Atmos. Chem. Phys. Discuss.: 18 April 2007

Revised: 18 July 2007 - Accepted: 7 August 2007 - Published: 9 August 2007

\begin{abstract}
The interactions between microbial and chemical contents of cloud water were investigated. First, we observe that the bulk cloud water solution provides a substantial environment where bacteria can develop significantly. Then, a total number of 60 microbial strains originating from seven distinct samples of cloud water and affiliated to various taxonomic groups were examined for their ability to degrade some of the main atmospheric carboxylic compounds: formate, acetate, lactate, succinate, as well as formaldehyde and methanol. Biodegradation tests show that all these compounds can be transformed when used as single carbonaceous substrates, with activities depending on both the strain and the compound. The highest capacities of biodegradation are observed towards formaldehyde, formate and acetate, which are also the more concentrated compounds typically measured in cloud water. Hence, analyses by ${ }^{1} \mathrm{H}$ NMR permitted to establish for instance that compounds like pyruvate or fumarate can be produced and released in the media in relation to the transformation of lactate or succinate. In addition, utilization of ${ }^{13} \mathrm{C}$ labelled formaldehyde showed that it can be transformed through many metabolic pathways, similar to those induced by photochemistry and leading to the production of formate and/or methanol. These results suggest that microorganisms of cloud water can have various behaviours towards the chemical compounds present in the atmosphere: they can represent either a sink or source for organic carbon, and may have to be considered as actors of cloud chemistry.
\end{abstract}

Correspondence to: A.-M. Delort

(a-marie.delort@univ-bpclermont.fr)

\section{Introduction}

Up to the last decade, the existence of a living microbial biota in fog and cloud water has been demonstrated (Fuzzi et al., 1997; Bauer et al., 2002; Amato et al., 2005), and the evidence of a possible metabolic activity under the conditions of temperature encountered in clouds was also given. The primary production resulting from the multiplication of microorganisms in clouds was estimated to reach 1 to $10 \mathrm{TgC}$ per year (Sattler et al., 2001). During previous investigations, we isolated a large variety of bacterial and fungal microorganisms from cloud water samples in which ATP concentration implied microbial activity (Amato et al., 2007b). This activity could be supported by the presence of substrates like atmospheric organic compounds, the chemistry of which has become a subject of increasing interest with the growing problems of air pollution. As suggested by Ariya and Amyot (2004), the microbiological component of clouds could interfere with the chemical processes occurring in droplets and finally have a non negligible influence on the chemical composition of cloud water.

Organic compounds are present in all the compartments of the atmosphere, the gaseous and particulate phases (Chameides and Davis, 1983; Puxbaum et al., 1988; Grosjean, 1989; Kumar et al., 1996; Sellegri et al., 2003), rain water (Kieber et al., 1999; Kawamura et al., 2001) and also in cloud water on which we focus in this paper (Voisin et al., 2000; Fuzzi et al., 2002; van Pinxteren et al., 2005; Parazols et al., 2006). Carboxylic acids, originating from both anthropogenic and biogenic sources, predominate and represent between $10 \%$ and more than $70 \%$ of the total dissolved organic carbon contained in cloud water (Löflund et al., 2002; Marinoni et al., 2004). High levels in aldehyde concentrations are strongly linked to human activities (Granby et al., 1997) and

Published by Copernicus Publications on behalf of the European Geosciences Union. 
to photochemistry (Riedel et al., 1999). Alcohols, though they are rarely measured due to analytical problems, have been detected in polluted fog water using nuclear magnetic resonance (NMR) (Suzuki et al., 1998). All these compounds are related to the oxidation of hydrocarbons, mainly emitted from anthropic activities. They are in addition strongly linked together by atmospheric chemistry. As an example in the case of $\mathrm{C}_{1}$ compounds, the transformation of methanol to formaldehyde, formate and finally to $\mathrm{CO}_{2}$ is catalyzed by free radicals produced by photochemical processes (Monod et al., 2000). For the moment, investigations concerning the capacity of such atmospheric compounds to be microbiologically transformed showed some very interesting potentialities (Ariya al., 2002; Amato et al., 2005), but they are limited to a very few micro-organisms, and a real overall picture is still not available. To address this deficiency, we present in this article results obtained from a large study, involving 60 microbial strains isolated from cloud water samples collected all along a period of almost two years, described elsewhere in a recently published paper (Amato et al., 2007b). Six organic compounds have been considered, among which four carboxylic acids (three monoacids (formate $\mathrm{C}_{1}$, acetate $\mathrm{C}_{2}$ and lactate $\mathrm{C}_{3}$ ) and one diacid (succinate $\mathrm{C}_{4}$ )), an aldehyde (formaldehyde $\mathrm{C}_{1}$ ) and an alcohol (methanol $\mathrm{C}_{1}$ ). An introductory observation is presented, proving the capacity of micro-organisms to develop under the nutritive conditions provided by cloud water.

\section{Material and methods}

\subsection{Capacity of cloud water to act as a nutritive medium}

A volume of cloud water sampled at the puy de Dôme summit as described in Amato et al. (2005) have been brought back to the laboratory for a further incubation at $17^{\circ} \mathrm{C}$, under agitation $(200 \mathrm{rpm})$. All precautions were taken to prevent contamination throughout the experiment. ATP concentration was measured by bioluminescence (luciferin/luciferase) for a period of about four days, on triplicate volumes of $0.2 \mathrm{~mL}$ sampled under sterile conditions. Reagents from a commercial kit (Biothema, ATP Biomass kit) were used, and measurements were made with a bioluminometer Biocounter M2500 (Lumac). In addition, total cell counts have been carried out by epifluorescence microscopy at the beginning and at the end of the incubation, in triplicates. Volumes of $7.5 \mathrm{~mL}$ were fixed with equal volumes of prefiltered $4-5 \%$ formaldehyde, incubated $20 \mathrm{~min}$ in the dark in the presence of $2.5 \mu \mathrm{g} \mathrm{mL}^{-1}$ of 4'-6-diamino-2-phenylindole (DAPI), filtered (GTBP $0.2 \mu \mathrm{m}$, Millipore) and filters were finally dried and mounted on slides to be observed. Cells present on random microscopic fields were counted (objective $\times 40$ for fungal cells, then $\times 100$ under immersion for bacteria), using a microscope Olympus BH-2.
2.2 Incubations of strains in the presence of organic compounds

For each isolated strain, liquid pure pre-culture was incubated at $17^{\circ} \mathrm{C}$ or $27^{\circ} \mathrm{C}$ in M200, TS (Biomerieux) or R2 (prepared according to the R2A Difco medium) broths. Pure cultures were then incubated under the same conditions and cells were harvested by centrifugation $\left(4000 \mathrm{~g}, 15 \mathrm{~min}, 4^{\circ} \mathrm{C}\right)$ after 24 or $48 \mathrm{~h}$ of growth, twice rinsed with $\mathrm{NaCl} 0.8 \%$ and finally suspended in the test media containing one of the compounds to degrade. The test media were composed of cells originating from a defined volume of culture with addition of about $20 \mathrm{mM}$ of sodium formate (Aldrich), lactic acid (mix of isomers L and D, approximately 70:30) (Touzard and Matignon), sodium succinate (Aldrich) or $2 \mathrm{mM}$ of formaldehyde and $0.8 \mathrm{mM}$ of methanol from a mixed aqueous solution of formaldehyde/methanol (Sigma 37\% v/v formaldehyde, stabilized with $\sim 15 \% \mathrm{v} / \mathrm{v}$ methanol) in $0.1 \mathrm{M}$ phosphate buffer at $\mathrm{pH}$ 7.0. The volume of culture used was adjusted based on its $\mathrm{OD}_{580 \mathrm{~nm}}$ to keep constant the ratio between cell density and concentration of the compound to degrade. For a given strain, all tests were performed using cells originating from a same culture flask, which was distributed between the tests solutions. One single compound was present in each of the incubation media, except for Land D-lactate and for formaldehyde/methanol. A blank constituted by cells and phosphate buffer was also systematically made. Incubations were carried out in $100 \mathrm{~mL}$ Erlenmeyer's flasks containing a final volume of $25 \mathrm{~mL}$, under agitation (200 rpm), at $17^{\circ} \mathrm{C}$ or $27^{\circ} \mathrm{C}$ depending on the optimal conditions for growth of the strain. Samples of about $1 \mathrm{~mL}$ were taken at the beginning and after $24 \mathrm{~h}$ of incubation, centrifuged (12000 g, $3 \mathrm{~min}$ ) and supernatants were kept frozen $\left(-40^{\circ} \mathrm{C}\right)$ until analysis.

\subsection{Organic acids and methanol quantifications by ${ }^{1} \mathrm{H}$ NMR}

Supernatants from biodegradation test media were prepared for ${ }^{1} \mathrm{H}$ NMR by mixing a volume of $450 \mu \mathrm{l}$ of the sample with $50 \mu \mathrm{l}$ of sodium tetra deuteriated trimethylsilyl propionate ( $\mathrm{TSPd}_{4}$, Eurisotop) in solution in $\mathrm{D}_{2} \mathrm{O}$. The latter was used for locking and shimming, while $\mathrm{TSPd}_{4}$ constituted a reference for chemical shifts $(0 \mathrm{ppm})$ and quantification. Final volumes of $500 \mu \mathrm{l}$ of prepared samples were put in $5 \mathrm{~mm}$ diameter tubes for NMR. Acquisition of spectra were made at $400.13 \mathrm{MHz}, 21^{\circ} \mathrm{C}$, on a Bruker Avance 400 spectrometer, by collection of 32 scans $\left(90^{\circ}\right.$ pulse, $4789.27 \mathrm{~Hz} \mathrm{SW}$, 65.536 data points, $6.84 \mathrm{~min}$ total acquisition time). Water signal was eliminated by presaturation, and no filter was applied before Fourier transformation. Using Bruker software (X-Win NMR), baseline was corrected before integration for quantification. The concentration of metabolites was calculated as follow: $[m]=\left(9 * A o *\left[\mathrm{TSPd}_{4}\right]\right) /\left(b^{*} A_{\text {ref }}\right)$, where $[m]$ is the concentration of the compound to quantify, $A o$ is the area 
of $m$ resonance, $A_{\text {ref }}$ is the area of $\mathrm{TSPd}_{4}$ resonance, and 9 and $b$ are respectively the numbers of protons of $\mathrm{TSPd}_{4}$, resonating at $0 \mathrm{ppm}$, and of $m$.

\subsection{Formaldehyde quantification}

Formaldehyde is not detectable by ${ }^{1} \mathrm{H}$ NMR due to its chemical shift of about 4.5 , and therefore is masked by the signal of water. A sensitive automatic analyser was used (Aerolaser AL4021). The principle is based on the reaction of formaldehyde with acetylacetone and ammoniac, resulting in the formation of the detected fluorochrome complex $\left(\lambda_{\text {excitation }}=400 \mathrm{~nm} ; \lambda_{\text {emission }}=510 \mathrm{~nm}\right)$, for which light emission is directly proportional to formaldehyde concentration.

2.5 Utilization of ${ }^{13} \mathrm{C}$ labelled formaldehyde and analysis by ${ }^{13} \mathrm{C}$ NMR

Incubation in the presence of ${ }^{13} \mathrm{C}$ labelled formaldehyde (Eurisotop, solution at $20 \% \mathrm{v} / \mathrm{v}$ ) was also carried out for three strains at $17^{\circ} \mathrm{C}$ and $5^{\circ} \mathrm{C}$, to follow the formaldehyde metabolism and unambiguously identify formed compounds as metabolites. Incubations were carried out as previously exposed, and acquisitions of ${ }^{13} \mathrm{C}$ NMR spectra were performed at $100.62 \mathrm{MHz}$ using the same $400 \mathrm{MHz}$ spectrometer as for ${ }^{1} \mathrm{H}$ NMR. 512 scans were collected $\left(90^{\circ}\right.$ pulse, $25125.63 \mathrm{~Hz} \mathrm{SW}, 65.536$ data points, $54.19 \mathrm{~min}$ total acquisition time), and spectra were treated using the X-Win NMR software. This method is not quantitative, and the analyser AL4021 and ${ }^{1} \mathrm{H}$ NMR have been used to quantify formaldehyde and formed labelled metabolites.

\section{Results and discussion}

3.1 Cloud water provides a nutritive medium for microbial growth

In order to investigate the capacity of cloud water to act as a nutritive medium for cells, a bulk cloud water sample collected in January 2005 was incubated a few hours after sampling without any supplementation in nutritive material. During sampling time, temperature averaged $-3.2^{\circ} \mathrm{C}, \mathrm{pH}$ was 6.8. This value of $\mathrm{pH}$ attests that this cloud event was not under anthropogenic influence. The evolution of the concentration of Adenosine Triphosphate (ATP), a key molecule for life, in this cloud sample incubated at $17^{\circ} \mathrm{C}$ is shown in Fig. 1, and the total bacteria counted at the beginning of the incubation and after $97 \mathrm{~h}$ are also plotted. We observe that after a lag time of about $45 \mathrm{~h}$ during which ATP concentration is rather constant, activity raises. This lag time could be attributed to the time required by cells for responding to the mechanical and thermal stresses caused by both the sampling method (impaction) and the further manipulations. After $90 \mathrm{~h}$, the concentration of ATP reaches

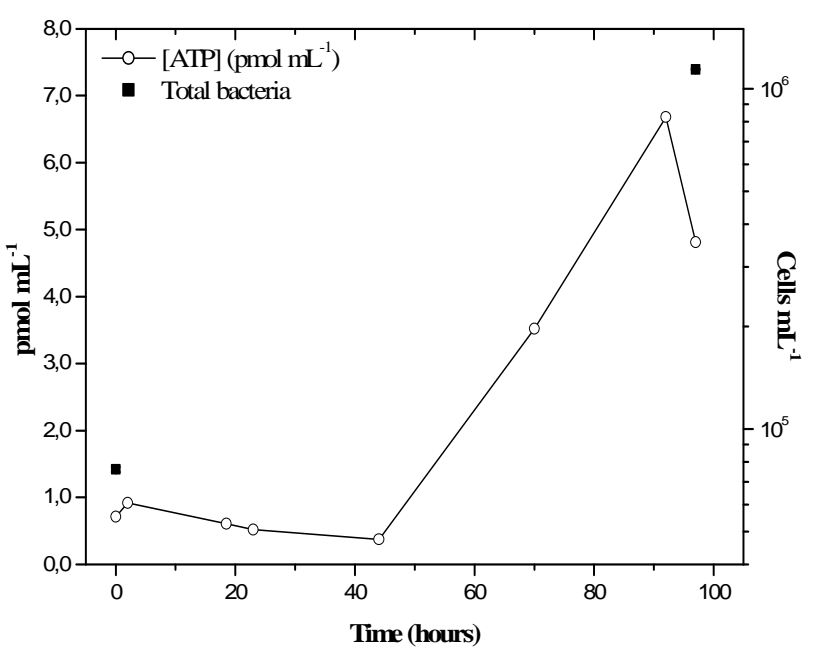

Fig. 1. Time-dependence of the concentration of adenosine triphosphate (ATP) in a bulk cloud water sample stored at $17^{\circ} \mathrm{C}$ under agitation $(200 \mathrm{rpm})$ and closed against exogenous contamination. Total cells were counted by epifluorescence microscopy at the beginning and at the end of the experiment. Fungal cells (not plotted) were respectively $2.7 \pm 0.6 \times 10^{3} \mathrm{~mL}^{-1}$ and $1.5 \pm 0.6 \times 10^{3} \mathrm{~mL}^{-1}$. Errors bars were obtained from triplicate measurements of ATP concentration but are masked by symbols.

about 7 times the value measured at the beginning. Furthermore, during that time, while fungal cells concentration is not significantly changed, total bacteria number is increased from $7.6 \times 10^{4} \pm 1.3 \times 10^{3} \mathrm{~mL}^{-1}$ to $1.1 \times 10^{6} \pm 4.6 \times 10^{3} \mathrm{~mL}^{-1}$. Such an observation clearly suggests that bacteria find nutrients to multiply in the liquid phase of clouds, and confirms the hypothesis made by Fuzzi et al. (1997). Chemical analysis of the sample (before incubation) showed that total organic carbon (TOC) was $2.8 \mathrm{mg} \mathrm{L}^{-1}$, with for instance presence of compounds like formate and acetate $(4 \mu \mathrm{M})$. Many other organic compounds were also measured or at least detected (succinate, malonate, oxalate, formaldehyde...) (Parazols et al., unpublished data). Ammonium $\mathrm{NH}_{4}^{+}$and nitrate $\mathrm{NO}_{3}^{-}$were respectively about $50 \mu \mathrm{M}\left(900 \mu \mathrm{g} \mathrm{L}^{-1}\right)$ and $25 \mu \mathrm{M}\left(1550 \mu \mathrm{g} \mathrm{L}^{-1}\right)$ and elements such as $\mathrm{P}, \mathrm{S}, \mathrm{Fe}, \mathrm{Mg}$, $\mathrm{Na}, \mathrm{K}$ were present. Regarding these data and assuming that a $\mathrm{C} / \mathrm{N} / \mathrm{P}$ ratio of $100 / 10 / 1$ is required for growth, carbon is the nutritive limiting factor for cell multiplication in clouds.

3.2 Efficiencies of biodegradation of atmospheric organic compounds by isolated strains

Biodegradation capacities of a total of 60 aerobic strains previously isolated from cloud water collected at the puy de Dôme summit (1465 m a.s.l.), including bacteria and yeasts, have been tested on formate, acetate, lactate, succinate, and on a mixed solution of formaldehyde and methanol. Numbers of 30 Gram positive, 20 Gram negative and 4 unidentified bacterial strains and 6 yeasts strains have been 


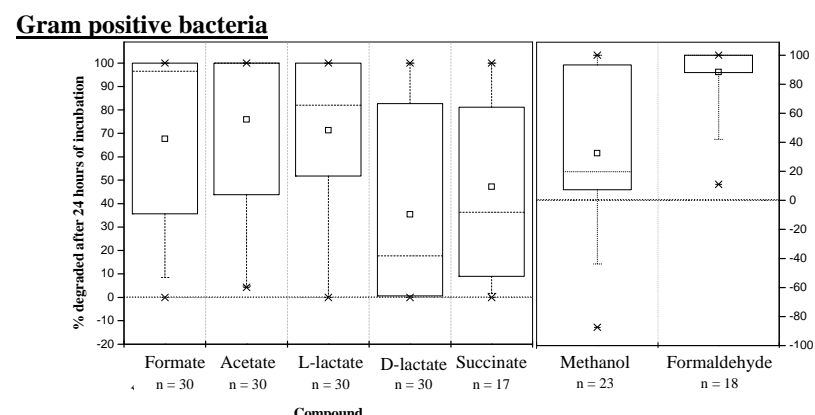

Gram negative bacteria

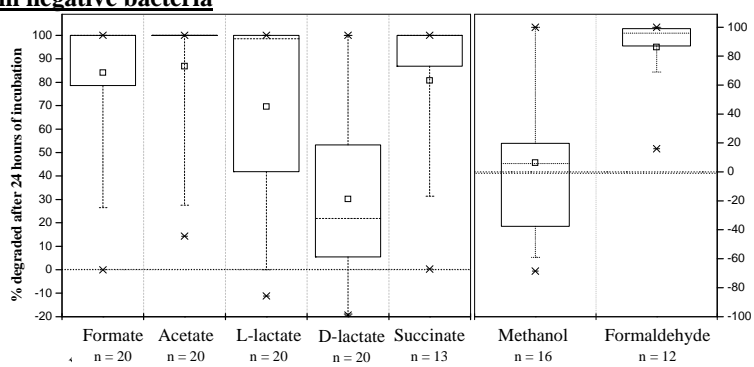

$\underline{\text { Yeasts }}$

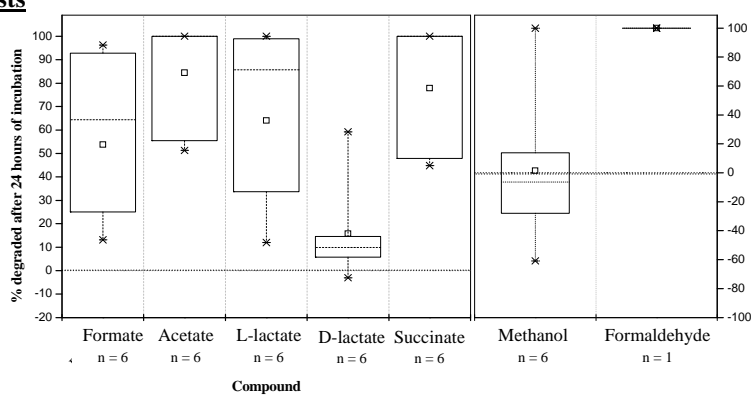

Fig. 2. Percentages of biodegradation for each compound by Gram positive and Gram negative bacteria and yeasts after $24 \mathrm{~h}$ of incubation. Boxes represent medians (-- -) and 25-75 percentiles; $\square$ means; $x$ minima and maxima. The number of strains considered in each case is indicated. Median is not precised when $n<5$.

investigated. NMR was used as analytical method as this allows both detection and quantification of organic compounds, rapidly and without any presumption.

Results are given separately for Gram positive, Gram negative and yeasts isolates in Fig. 2, giving an overview of the potentialities of all the tested strains. In Fig. 3, biodegradation efficiencies of the strains belonging to the main bacterial genera recovered from our cloud water samples and yeasts are detailed for each compound (3 strains of Arthrobacter, 3 of Micrococcus, 6 of Bacillus, 7 of Staphylococcus, 5 of Sphingomonas, 9 of Pseudomonas and 6 yeasts) (see Amato et al., 2007a). These two figures will be discussed simultaneously within this section. Means and medians are generally distinct, indicating that data does not follow Gaussian shaped distributions. The former has thus been preferred to compare results to others.
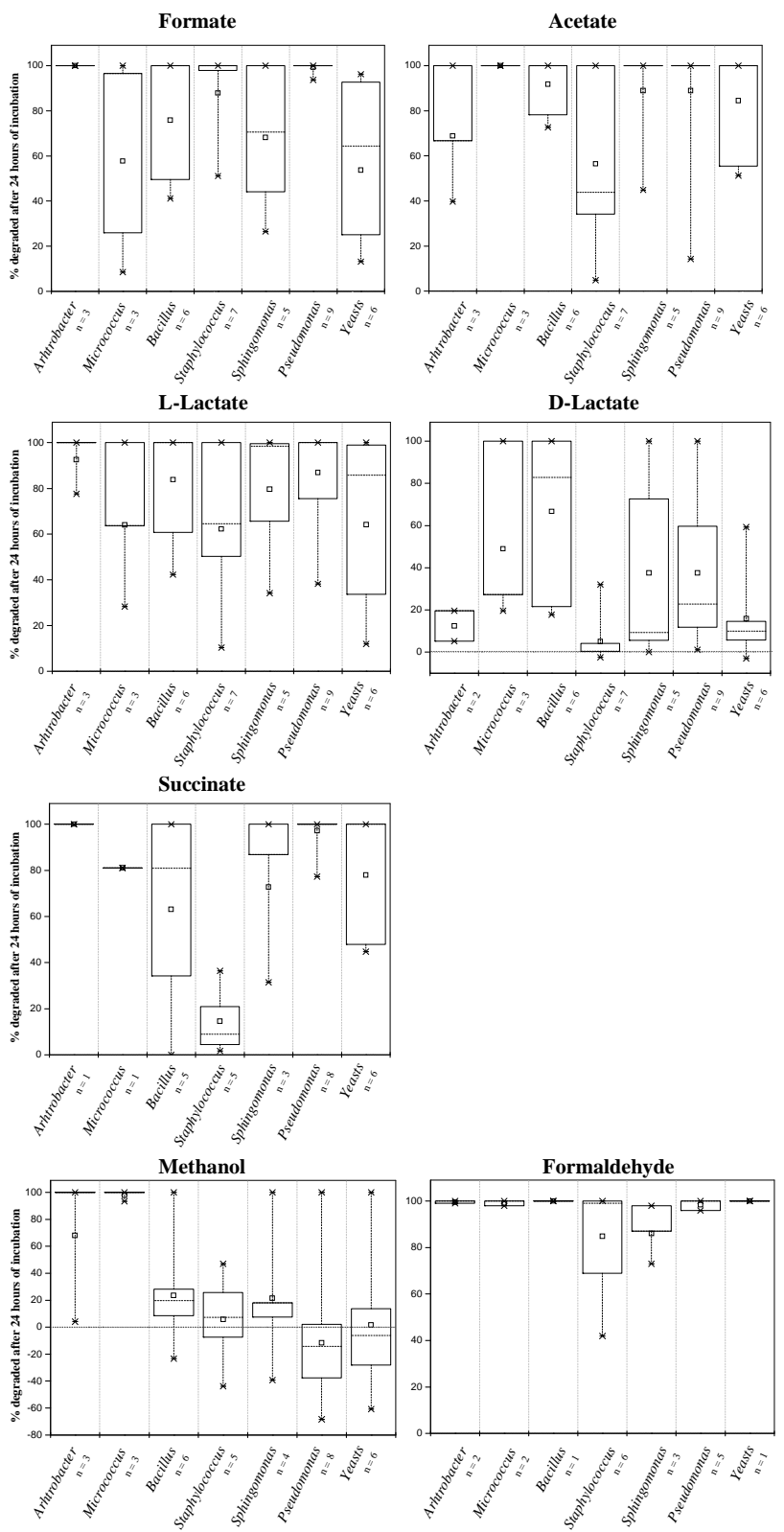

Fig. 3. Percentages of biodegradation for each compound by main genera of bacteria and total yeasts found in cloud water, after $24 \mathrm{~h}$ of incubation (Arthrobacter, Micrococcus, Bacillus, Staphylococcus, Sphingomonas and Pseudomonas and yeasts). Boxes represent medians (- -) and 25-75 percentiles; $\square$ means; $\times$ minima and maxima. The number of strains considered in each case is indicated. Median is not precised when $n<5$.

On the whole, highest efficiencies of degradation are observed for Gram negative bacteria (Fig. 2). It is of first interest since Gram negative bacteria such as Pseudomonas species are thought to be the more active cells present in clouds, as they often develop at low temperature (Amato et al., 2007a). In addition, formate, acetate and formaldehyde 
Table 1. Carboxylic acids tested, ${ }^{1} \mathrm{H}$ NMR chemical shifts of the groups in bold (respect to $\mathrm{TSPd}_{4}$, at $\mathrm{pH} 7.0$ ) and related metabolites detected in the incubation media.

\begin{tabular}{|c|c|c|c|}
\hline Compound & & Chemical shift (ppm) & Metabolite(s) detected \\
\hline Formate & $\mathbf{H}-\mathrm{COO}^{-}$ & 8.46 , singlet & None \\
\hline Acetate & $\mathbf{H}_{3} \mathrm{C}-\mathrm{COO}^{-}$ & 1.92 , singlet & $\begin{array}{l}\text { Triplet at } 1.05 \mathrm{ppm} \text { not attributed } \\
\text { Doublets at } 5.80 \mathrm{ppm} \text { and } 7.55 \mathrm{ppm} \text { not attributed }\end{array}$ \\
\hline Lactate & $\mathbf{H}_{3} \mathrm{C}-\mathrm{CHOH}-\mathrm{COO}^{-}$ & $\begin{array}{l}1.45, \text { doublet }(\mathrm{L} \text { isomer) } \\
1.33 \text {, doublet ( } \mathrm{D} \text { isomer) }\end{array}$ & $\begin{array}{l}\text { Acetate }(1.92 \mathrm{ppm}, \text { singlet }) \\
\text { Pyruvate }(2.38 \mathrm{ppm}, \text { singlet }) \\
\text { Triplets at } 2.4 \text { and } 3.0 \mathrm{ppm} \text { not attributed }\end{array}$ \\
\hline Succinate & ${ }^{-} \mathrm{OOC}-\left(\mathrm{CH}_{2}\right)_{2}-\mathrm{COO}^{-}$ & 2.41 , singlet & $\begin{array}{l}\text { Acetate }(1.92 \mathrm{ppm} \text {, singlet }) \\
\text { Fumarate }(6.50 \mathrm{ppm} \text {, singlet }) \\
\text { Triplet at } 3.00 \mathrm{ppm} \text { not attributed } \\
\text { Singlets at } 1.35 \mathrm{ppm}, 1.50 \mathrm{ppm} \text { and } 5.45 \mathrm{ppm} \text { not attributed }\end{array}$ \\
\hline
\end{tabular}

appear to be the more actively transformed compounds, and they are also the more concentrated organic compounds found in cloud water. All these results support a potential activity of biodegradation of those compounds in cloud water.

For formate, Gram negative bacteria, Gram positive bacteria and yeasts degrade respectively, in median, 100\%, 97\% and $65 \%$ of the amount present at the beginning of the test (Fig. 2). Only a few strains have a poor activity toward this compound, especially Micrococcus, Sphingomonas and yeasts strains looking at the main microorganisms (Fig. 3). On the contrary, all of the strains of Arthrobacter and Pseudomonas affiliations completely remove formate from the incubation media within $24 \mathrm{~h}$.

A large majority of strains degrade acetate very efficiently, especially among Gram negative and yeasts isolates (Fig. 2). For the main genera present in cloud water, highest activities are noticed among Micrococcus, Sphingomonas and Pseudomonas groups, for which percentages of biodegradation reach $100 \%$ in most of the cases (Fig. 3). On the other hand, Staphylococcus species regroup the less efficient strains with a median situated under the value of $40 \%$.

For lactate, as expected, biodegradation is dependent on the isomer form considered, and is always better in the case of L-lactate (Fig. 2). Indeed, medians are ranging from $60 \%$ (Staphylococcus group) to $100 \%$ (Bacillus and Pseudomonas groups) for the latter, while it reaches less than $50 \%$ for a large majority of strains for D-lactate, and is even close to $0 \%$ for the entire Staphylococcus group (Fig. 3). Only a few strains are able to degrade D-lactate, especially among those belonging to Micrococcus and Bacillus (Fig. 3). For some Staphylococcus and yeasts strains, an increase of concentration of D-lactate is even observed (negative value of biodegradation), likely resulting from the transformation of L-lactate by a racemase.

Concerning succinate, percentages of biodegradation are very variable from one group to another (Fig. 2), often greater than $90 \%$ among Gram negative bacteria, but lower than $20 \%$ for 4 out of the 5 Staphylococcus strains (Gram positive) (Fig. 3).

Methanol and formaldehyde were studied mixed in the incubation media since a commercial solution in which formaldehyde is stabilized by the presence of methanol was used. In this particular case, the rapid elimination of formaldehyde seems to be a priority for cells: almost all strains are able to transform the total amount of this compound within $24 \mathrm{~h}$. A related production of methanol (resulting in a negative value of biodegradation) is consequently often observed. Figures 2 and 3 show that Gram positive bacteria highly transform both formaldehyde and methanol, while methanol often accumulates in the cases of Gram negative (especially Pseudomonas) and yeasts strains.

\subsection{Specificities of microbial groups toward the proposed substrates}

From a biochemical point of view, several metabolic behaviours toward the different compounds are encountered among the main groups isolated from cloud water (Fig. 3). First, we can argue that strains of the genus Staphylococcus have a great specificity for formate, being less efficient than all the other groups toward each of the other compounds. Sphingomonas and yeasts are poor consumers of formate and prefer acetate, L-lactate or succinate. Micrococcus is situated between these two extremes, degrading methanol and formaldehyde very efficiently, but not formate. Bacillus strains seem to have no special requirement, as well as Arthrobacter and Pseudomonas, except D-lactate for the former and methanol for the latter.

\subsection{Pathways of biodegradation of carboxylic acids}

The metabolic pathways involved in the biotransformation of carboxylic acids cannot be determined with certitude by solely considering the data presented here. However, it gives 
(a)

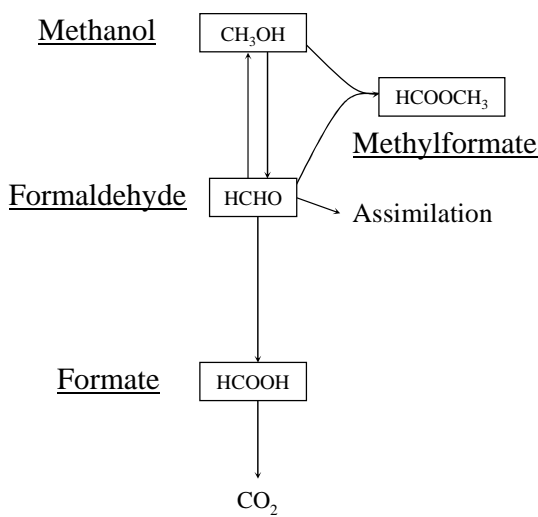

(b)

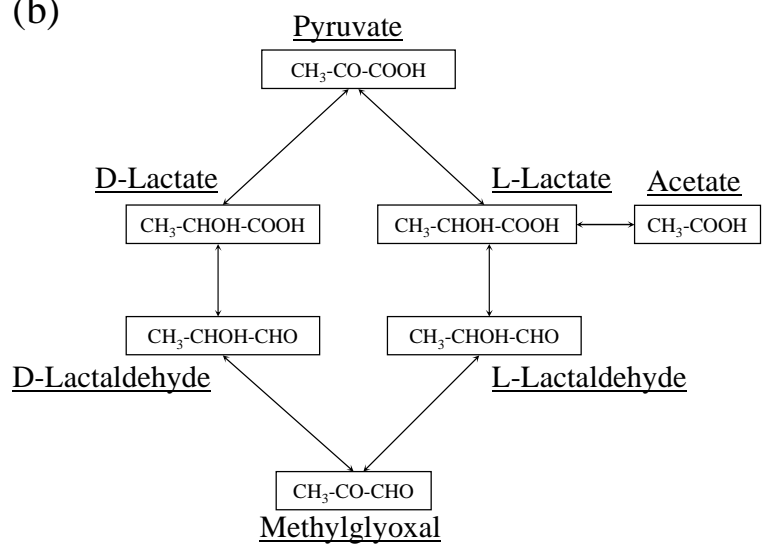

(c)

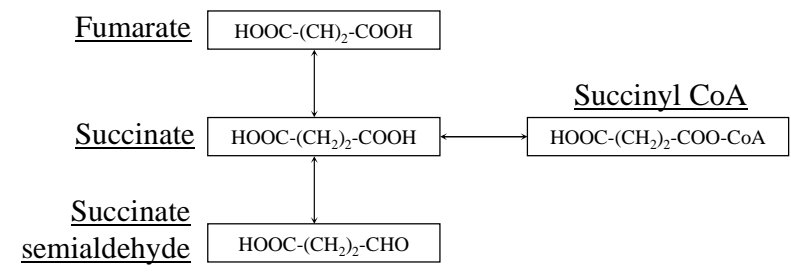

Fig. 4. Schematic representation of known metabolic pathways involving methanol, formaldehyde and formate (a), lactate (b) and succinate (c).

indications when metabolites are released in the solution and are consequently detected by ${ }^{1} \mathrm{H}$ NMR analysis. Table 1 reports the chemical shifts and multiplicity of signals related to the tested carboxylic acids, and of signals that can be attributed to metabolites (i.e. when they are not detected in the corresponding blank).

Formate is the smaller existing carboxylic acid, and microbial metabolism can only lead to its direct oxidation to carbon dioxide (KEGG Metabolic Pathway database) (see Fig. 4a). As a consequence, no metabolite is detected for this compound.

Acetate is a link taking place in many routes of the central metabolism mainly through the complexation with Coen- zyme A to enter the Krebs cycle. In addition, the uptake of acetate by cells does not require, most of the time, any carrier system as it diffuses through the cytoplasmic membrane (Kell et al., 1981). This certainly explains the high capacity of biodegradation generally noticed whatever the microbial group considered. However, few strains present a low activity toward this substrate, especially among genera Bacillus and Staphylococcus for Gram positive bacteria, and a very low value (5\%) is observed for an Actinobacteria: Frigoribacterium sp. PDD14b-13 (DQ512796). In some cases, unidentified products are released in the incubation media containing acetate, resonating as doublets at $5.80 \mathrm{ppm}$ and $7.5 \mathrm{ppm}$, or as a triplet at $1.05 \mathrm{ppm}$ (Fig. 5a).

For lactate, different metabolic pathways exist depending on the isomer form $\mathrm{L}$ or $\mathrm{D}$ (Fig. $4 \mathrm{~b}$ ). A racemase is known to be involved in the transformation of an isomer form of lactate to the other (Kitahara et al., 1953), but is rarely encountered referring to the KEGG database. For both forms, lactate can enter the central microbial metabolism either by oxidation to pyruvate or reduction to lactaldehyde (it can also link coenzyme A; not shown on the scheme). A fourth way involves only L-lactate, and consists in its decarboxylation, leading to the production of acetate. Acetate $(\delta=1.92 \mathrm{ppm})$ and pyruvate $(\delta=2.38 \mathrm{ppm})$ productions were actually unambiguously identified, while the apparition of non identified triplet signals is often observed $(\delta=2.4 \mathrm{ppm}$ and $3.0 \mathrm{ppm}$ ) (Fig. 5b). Interestingly, as D-lactate concentration increases when both isomers are present (leading to a negative value of biodegradation), two Gram negative bacterial strains likely express a lactate racemase: Methylobacterium sp. PDD7b-5 (DQ512770) and Flavobacterium sp. PDD14b-7 (DQ512791). Low levels of pyruvate in cloud water have been reported by Löflund and collaborators (2002), and one could see here the signature of such a biological activity.

Succinate is largely involved in the central metabolism (Krebs cycle) and represents a metabolic link between succinyl-CoA and fumarate (Fig. 4c). Its oxidation to fumarate is directly linked to the production of ATP, as it takes place in the oxidative phosphorylation. A compound resonating as a singlet at $6.5 \mathrm{ppm}$ is produced in many cases. This signal likely corresponds to the $\mathrm{CH}$ group in fumarate ( $\mathrm{HOOC}-\mathrm{HC}=\mathrm{CH}-\mathrm{COOH}$ ) (Fig. 5c). A release of acetate is also observed, as well as an unidentified product resonating as a triplet centred at $3.0 \mathrm{ppm}$. The latter may also be related to one of the two triplets detected by incubation with lactate $(\delta=2.4 \mathrm{ppm}$ and $3.0 \mathrm{ppm})$, the other being masked by the signal of succinate itself. Other non assigned singlets are also detected following the biodegradation of succinate.

\subsection{Metabolism of methanol and formaldehyde}

Values of biodegradation determined for methanol are highly variable, ranging from about $-80 \%$ (production of methanol) to $100 \%$ (Fig. 2). The concentration of methanol measured 


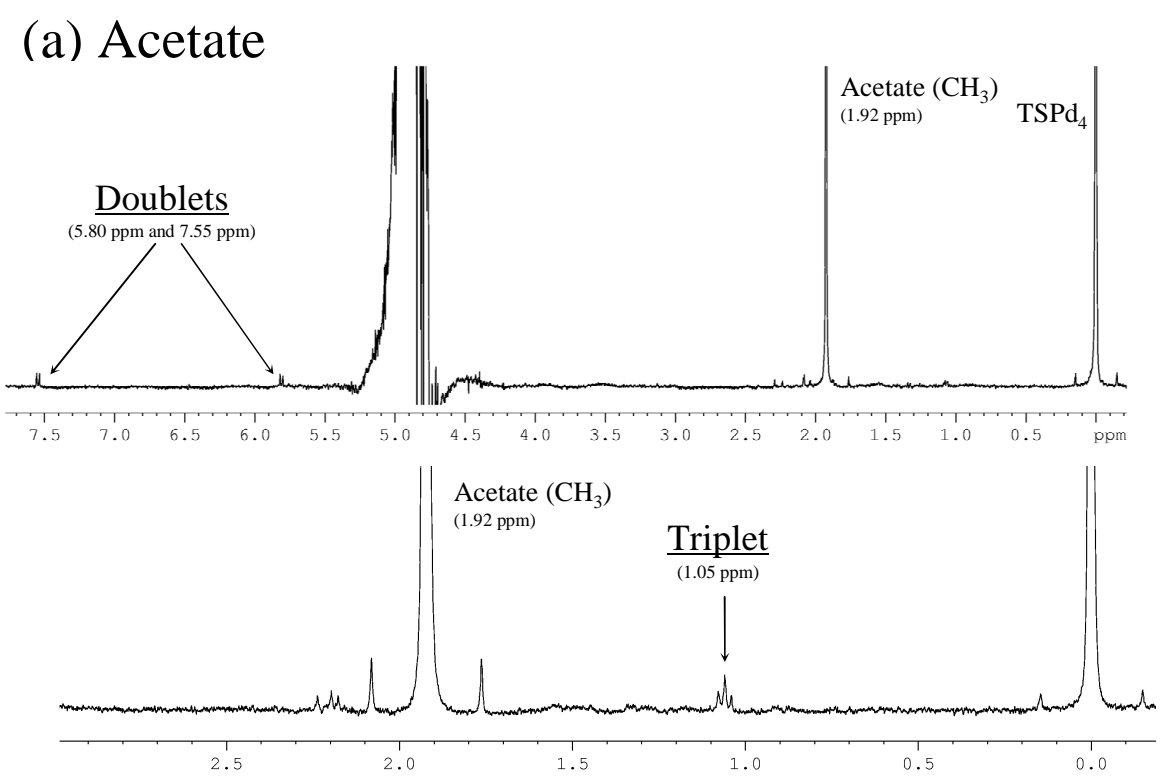

(b) Lactate

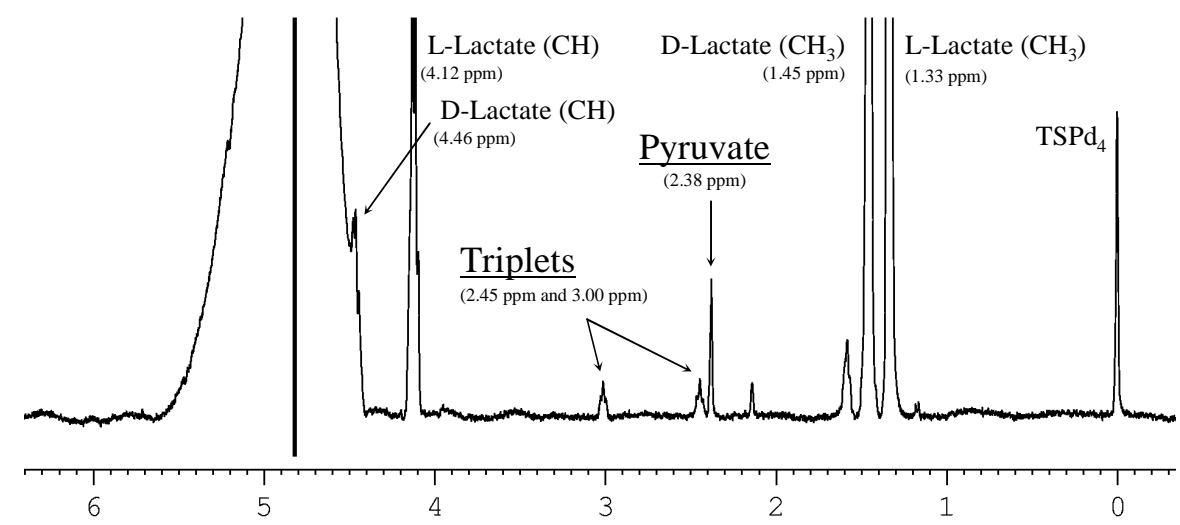

(c) Succinate

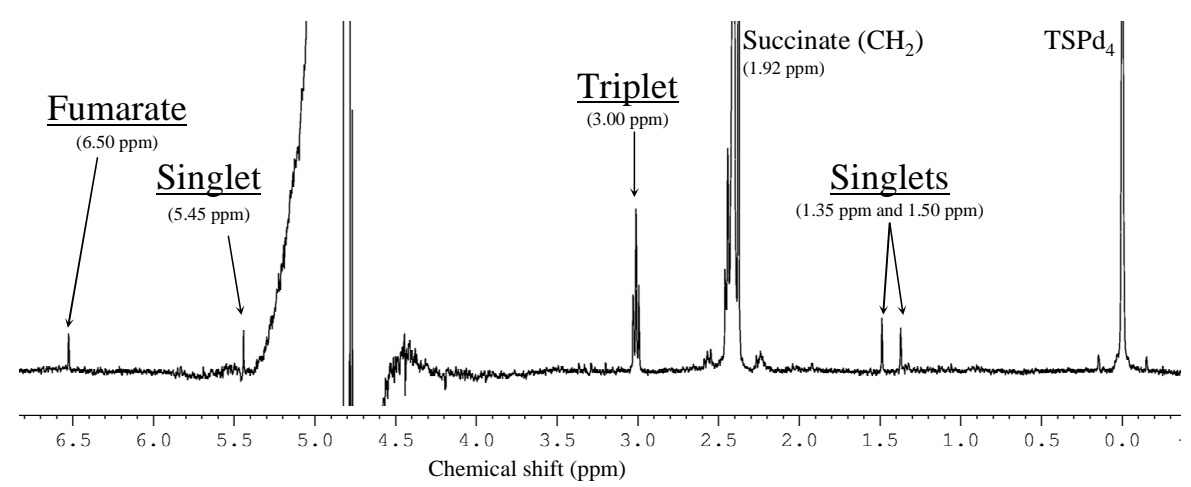

Fig. 5. Examples of ${ }^{1}$ H NMR spectra showing signals appearing during incubation with acetate (a), lactate (b) and succinate (c). Spectra presented on (a) were obtained with strains of Bacillus sp. (upper trace)) and Curtobacterium flaccumfaciens (lower trace); on (b) Pseudomonas viridiflava and on (c) Curtobacterium flaccumfaciens. The large signal around $5 \mathrm{ppm}$ corresponds to the peak of water. 


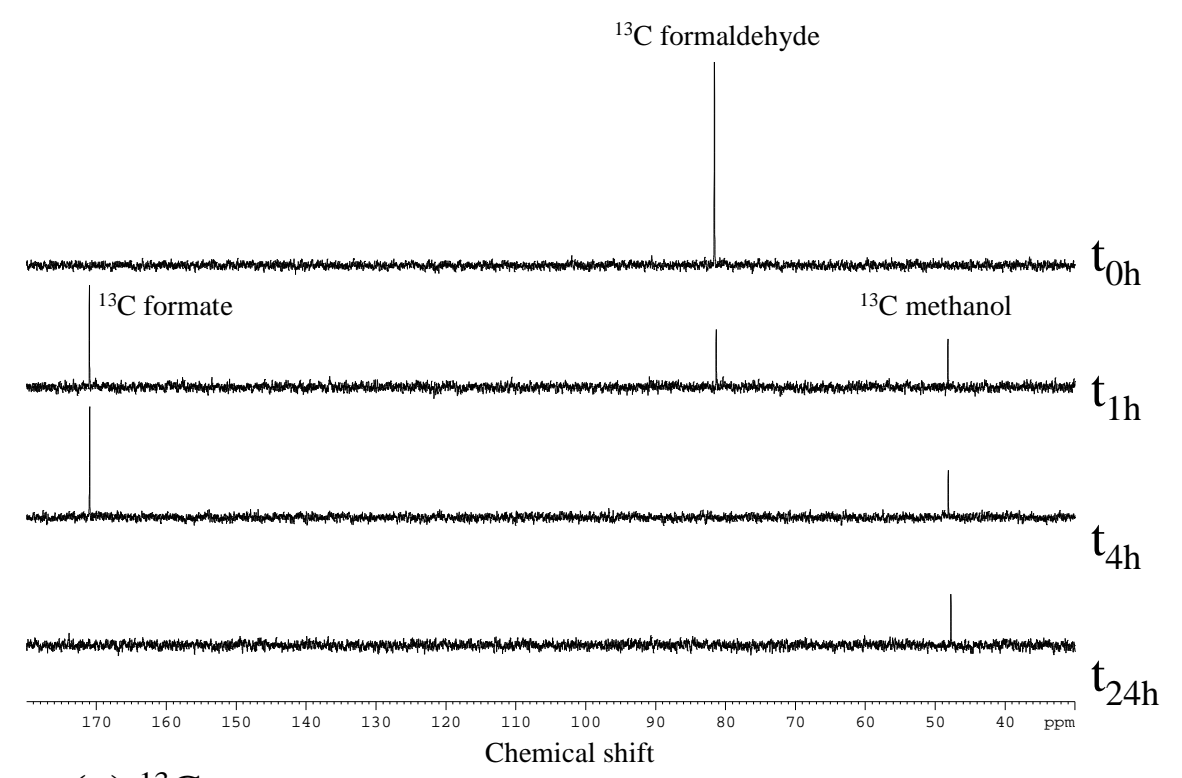

(a) ${ }^{13} \mathrm{C}$ spectra

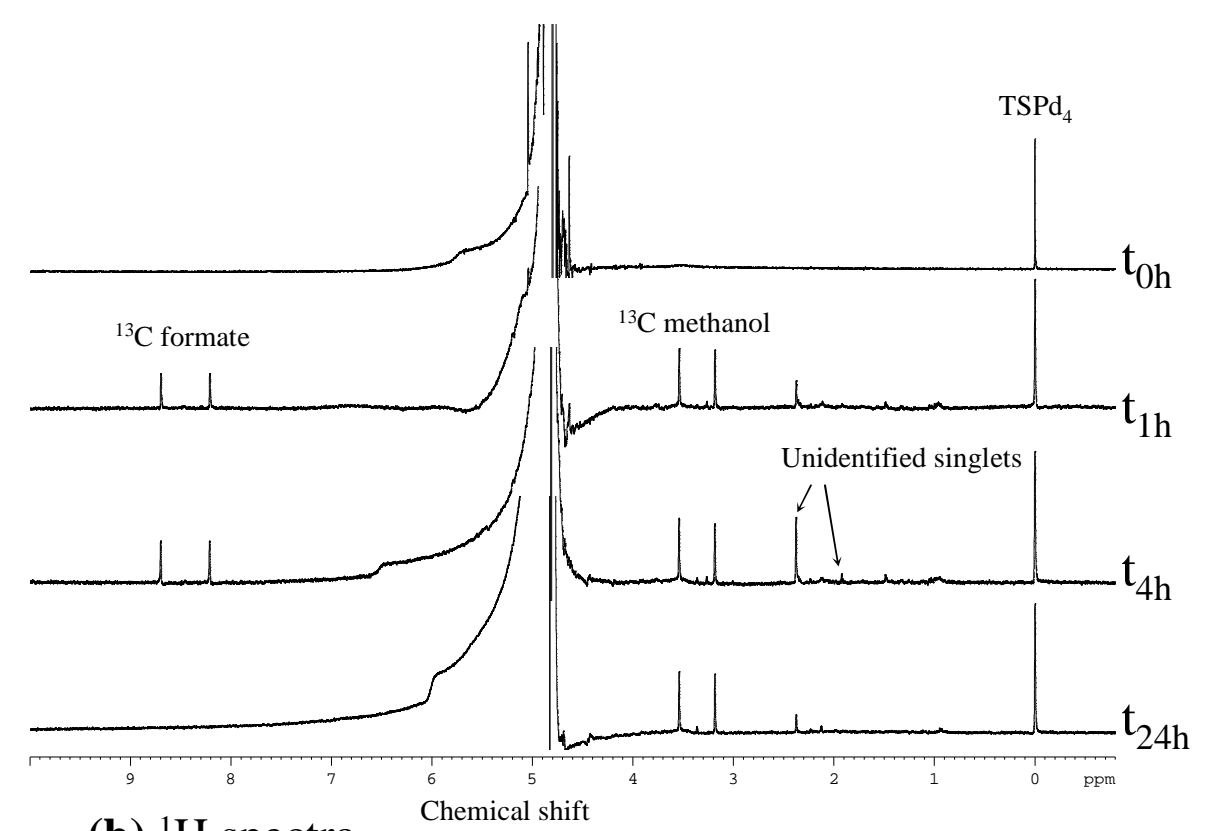

(b) ${ }^{1} \mathrm{H}$ spectra

Fig. 6. (a) ${ }^{13} \mathrm{C}$ NMR spectra showing the transformation of ${ }^{13} \mathrm{C}$ formaldehyde present at the beginning into ${ }^{13} \mathrm{C}$ methanol and ${ }^{13} \mathrm{C}$ formate during the time of incubation (example of the strain Frigoribacterium sp. PDD14b-13 (DQ512796) incubated at $17^{\circ} \mathrm{C}$. (b) Corresponding ${ }^{1} \mathrm{H}$ NMR spectra, with doublets related to ${ }^{13} \mathrm{C}$ labelled compounds. Singlet signals are related to non labelled compounds.

in our analysis results from the equilibrium between on one hand its degradation to formaldehyde, and on one other hand its production from formaldehyde (see Fig. 3a). All microbial groups degrade formaldehyde very efficiently, and the latter consequently does not accumulate when methanol is oxidized. Considering the known high toxicity of formaldehyde, the priority for the cells is likely to reduce its concentration, and in many cases methanol concentration is thus increasing within the $24 \mathrm{~h}$ of the test.
In order to unequivocally identify the metabolites produced from formaldehyde, we incubated one selected strain in the presence of pure (meaning single) ${ }^{13} \mathrm{C}$ labelled formaldehyde. This strain was arbitrary chosen amongst bacteria for its interesting behaviour toward the mixed solution of formaldehyde /methanol. It was identified as an Actinobacterium: Frigoribacterium sp. PDD14b-13 (DQ512796). Four fates of formaldehyde are known to be possible through microbial metabolic pathways 
(Fig. 3a): (i) its assimilation by the serine and/or the ribulose monophosphate pathways (the latter involves a decarboxylation); (ii) its reduction to methanol; (iii) its oxidation to formate; and (iv) its reaction with methanol, forming methylformate $\left(\mathrm{HCOOCH}_{3}\right)($ Mason and Sanders, 1989; Murdanoto et al., 1997; Delort, 2006). The second and third ways involve an oxydoreductase and/or a dismutase (Kato et al., 1984), the latter simultaneously producing formate and methanol from two molecules of formaldehyde. In addition, several known formaldehyde dehydrogenases are only dedicated to formaldehyde reduction (Vorholt, 2002), and a methanol dehydrogenase catalyzes the production of formaldehyde.

Analyses of the related supernatants by ${ }^{13} \mathrm{C}$ NMR clearly show that this strain of Frigoribacterium highly transforms formaldehyde to formate and methanol (Fig. 6). After less than $4 \mathrm{~h}$, no formaldehyde remains in the solution containing approximately $2 \mathrm{mM}$ at the beginning. Then, formate is oxidized to $\mathrm{CO}_{2}$, while methanol is still not transformed after $24 \mathrm{~h} .{ }^{1} \mathrm{H}$ NMR spectrum of the same supernatants also exhibit the presence of ${ }^{13} \mathrm{C}$ formate and ${ }^{13} \mathrm{C}$ methanol, the doublet-shaped signals indicating that compounds are actually labelled with ${ }^{13} \mathrm{C}$ originating from formaldehyde. In addition, other compounds are released, corresponding to signals at $1.45 \mathrm{ppm}, 1.95 \mathrm{ppm}, 2.4 \mathrm{ppm}$ and $2.15 \mathrm{ppm}$, resonating as singlets. Such signals possibly correspond either to non labelled metabolites due to a decarboxylation following their assimilation (loss of the ${ }^{13} \mathrm{C}$ to ${ }^{13} \mathrm{CO}_{2}$ ) or to metabolites produced from endogenous compounds. In the atmosphere, formaldehyde is strongly linked to free radical chemistry (Satsumabayashi et al., 1995; Riedel et al., 1999; Kawamura et al., 2005), and is so of first interest. Monod et al. (2000) studied photochemistry of methanol in aqueous phase and showed that free radicals produced by solar light also oxidize methanol to formaldehyde and formate.

\section{Conclusions}

In this study we investigated interactions between microorganisms and the chemical environment provided by cloud water. First we observed that, as it was discussed for several years, cloud water solution can provide a niche for the multiplication of bacteria supported by the organic compounds it contains. As a consequence, the uptake of chemical compounds by micro-organisms could have an effect on the composition of cloud water, assumed to be of primary importance in atmospheric chemistry. Biodegradation tests of various single organic compounds present in cloud water performed on 60 microbial strains (bacteria and yeasts) previously isolated from cloud water samples show a high activity on acetate, formate, L-lactate and formaldehyde. These are also the main organic compounds found in cloud water. Biodegradation of D-lactate appears to be relatively low. Various trends are observed, partially depending on the genus considered. For instance, Staphylococcus species are spe- cialized toward $\mathrm{C}_{1}$ compounds degradation, and such trends have to be kept in mind for the further investigations.

Several metabolites were detected, like pyruvate from lactate oxidation, or fumarate from succinate. These compounds were actually measured in cloud samples, and their presence could thus be partially attributed to such a microbial activity. More than being simply of biochemical interest, this clearly shows that cells can represent a sink, but also a source of organic compounds in cloud water.

Metabolisms of methanol and formaldehyde are strongly linked, and incubations in the presence of ${ }^{13} \mathrm{C}$ labelled formaldehyde bring the proof that both oxidation and reduction of formaldehyde can be microbiologically catalysed by microbes found in cloud water. Such reactions are also known to be induced by light. Hence, microbiological and photochemical processes can act conversely or simultaneously on the chemistry of cloud water. Consequently, the concentration of a given compound can be negatively as well as positively influenced by biology. Thus actual models of atmospheric chemistry could under- or overestimate the weight of some reactions by considering only the reactivity linked to photochemistry.

Though the chosen experimental conditions do not match those encountered in clouds (these environments consist in a complex solution distributed in micron sized droplets, and some physico-chemical properties can be limiting for metabolism: low temperature and $\mathrm{pH}$, high UV light and oxidative capacity), our investigations demonstrated that microorganisms present in clouds have an enzymatic pool that could potentially significantly affect atmospheric organic chemistry.

The large overview presented here shows that further research is needed to explain fully microbiological contribution to cloud chemistry since a real ability is depicted. Some hints are given and characteristics of cloud water should now be considered by experimental conditions, with the goal to approach or even mimic a real cloud. The relatively short lifetime of a cloud droplet also has to be taken in account. Anthropogenic pollution is known to prolong the lifetime of clouds, then microbial effects should be greater under these circumstances. But as a first step, we recommend having a special emphasis on the genus Pseudomonas, among which the most rapidly metabolizing bacteria were observed.

In order to figure out what is the influence of each limiting factor on the efficiency of biodegradation, each of them has to be added in the experimental conditions at once. Temperature is certainly one of the most important of these factors, and the next step is thus to determine metabolic constants under low temperature. 
Acknowledgements. The research was funded by the French LEFE-CHAT from the CNRS and the ORE-BEAM program of the French Ministry of Research. P. Amato is also the recipient of a scholarship from the French Ministry of Research. A. Melaouhi is under an AUF fellowship. E. Cano is greatly acknowledged for her technical help.

Edited by: J. Williams

\section{References}

Amato, P., Ménager, M., Sancelme, M., Laj, P., Mailhot, G., and Delort, A-M.: Microbial population in cloud water at the Puy de Dôme: implications for the chemistry of clouds, Atmos. Environ., 39, 4143-4153, 2005.

Amato, P., Parazols, M., Sancelme, M., Laj, P., Mailhot, G., and Delort, A-M.: Microorganisms isolated from the water phase of tropospheric clouds at the puy de Dôme: major groups and growth abilities at low temperature, FEMS Microbiol. Ecol., 59, 255-264, 2007a.

Amato, P., Parazols, M., Sancelme, M., Mailhot, G., Laj, P., and Delort, A-M.: An important oceanic source of micro-organisms for cloud water at the puy de Dôme (France), Atmos. Environ., in press, doi:10.1016/j.atmosenv.2007.06.022, 2007b.

Ariya, P. A., Nepotchatykh, O., Ignatova, O., and Amyot, M.: Microbiological degradation of atmospheric organic compounds, Geophys. Res. Lett., 29, 2077-2081, 2002.

Ariya, P. A. and Amyot, M.: New directions: the role of bioaerosols in atmospheric chemistry and physics, Atmos. Environ., 38, 1231-1232, 2004.

Bauer, H., Kasper-Giebl, A., Löflund, M., Giebl, H., Hitzenberger, R., Zibuschka, F., and Puxbaum, H.: The contribution of bacteria and fungal spores to the organic carbon content of cloud water, precipitation and aerosols, Atmos. Res., 64, 109-119, 2002.

Chameides, W. L. and Davis, D. D.: Aqueous-phase source for formic acid in clouds, Nature, 304, 427-429, 1983.

Delort, A-M.: Use of NMR to study in situ bioconversion of gaseous compounds, Chapter 9, in: Gas resources for resource recovery, edited by: Lens. P., IWA Publishing, London, 117-131, 2006.

Fuzzi, S., Mandrioli, P., and Perfetto, A.: Fog droplets - An atmospheric source of secondary biological aerosol particles, Atmos. Environ., 31, 287-290, 1997.

Fuzzi, S., Facchini, M. C., Decesari, S., Matta, E., and Mircea, M.: Soluble organic compounds in fog and cloud droplets: what have we learned over the past few years?, Atmos. Res., 64, 89-98, 2002.

Granby, K., Christensen, C. S., and Lohse, C.: Urban and semi-rural observations of carboxylic acids and carbonyls, Atmos. Environ., 31, 1403-1415, 1997.

Grosjean, D.: Organic acids in south California air: ambient concentrations, mobile source emissions, in situ formation and removal processes, Environ. Sci. Technol., 23, 1506-1514, 1989.

Kato, N., Kobayashi, T., Shimao, M., and Sakazawa, C.: Properties of formaldehyde dismutation catalyzing enzyme of Pseudomonas putida F61-a, J. Biotechnol., 1, 295-273, 1984.

Kawamura, K., Steinberg, S., Ng, L., and Kaplan, I. R.: Wet deposition of low molecular weight mono- and di-carboxilic acids, aldehydes and inorganic species in Los Angeles, Atmos. Environ., 35, 3917-3926, 2001.

KEGG PATHWAY database (Kyoto Encyclopedia of Genes and Genomes) http://www.genome.jp/kegg/pathway.html, last access: January 2007.

Kell, D. B., Peck, M. W., Rodger, G., and Morris, J. G.: On the permeability of weak acids and bases of the cytoplasmic membrane of Clostridium pasteurianum, Biochem. Biophys. Res. Commun., 99, 81-88, 1981.

Kieber, R. J., Rhines, M. F., Willey, J. D., and Brooks Avery Jr., D.: Rainwater formaldehyde: concentration, deposition and photochemical formation, Atmos. Environ., 33, 3659-3667, 1999.

Kitahara, K., Obayashi, A., and Fukui, S.: Racemase I cell-free racemase, Enzymologia, 15, 259-266, 1953.

Kumar, N., Kulshrestha, U. C., Khare, P., Saxena, A., Kumari, K. M., and Srivastava, S. S.: Measurements of formic and acetic acid levels in the vapor phase at Dayalbagh, Agra, India, Atmos. Environ., 30, 20, 3545-3550, 1996.

Löflund, M., Kasper-Giebl, A., Schuster, B., Giebl, H., Hitzenberger, R., and Puxbaum, H.: Formic, acetic oxalic and succinic acid concentrations and their contribution to organic carbon in cloud water, Atmos. Environ., 36, 1553-1558, 2002.

Marinoni, A., Laj, P., Sellegri, K., and Mailhot, G.: Cloud chemistry at the puy de Dôme: variability and relationships with environmental factors, Atmos. Chem. Phys., 4, 715-728, 2004, http://www.atmos-chem-phys.net/4/715/2004/.

Mason, R. P. and Sanders, J. K.: In vivo enzymology: a deuterium NMR study of formaldehyde dismutase in Pseudomonas putida F61a and Staphylococcus aureus, Biochemistry, 28, 2160-2168, 1989.

Monod, A., Chebbi, A., Durand-Jolibois, R., and Carlier, P.: Oxidation of methanol by hydroxyl radicals in aqueous solution under simulated cloud droplet conditions, Atmos. Environ., 34, 52835294, 2000.

Murdanoto, A. P., Sakai, Y., Konishi, T., Yasuda, F., Tani, Y., and Kato, N.: Purification and properties of methyl formate synthase, a mitochondrial alcohol dehydrogenase, participating in formaldehyde oxidation in methylotrophic yeasts, Appl. Environ. Microbiol., 63, 1715-1720, 1997.

Parazols, M., Marinoni, A., Amato, P., Abida, O., Laj, P., and Mailhot, G.: Speciation and role of iron in cloud droplets at the puy de Dôme station, J. Atmos. Chem., 54, 267-281, 2006.

Puxbaum, H., Rosenberg, C., Gregori, M., Lanzerstorfer, C., Ober, E., and Winiwarter, W.: Atmospheric concentrations of formic and acetic acid in eastern and northern Austria, Atmos. Environ., 22, 2841-2850, 1988.

Riedel, K., Weller, R., and Schrems, O.: Variability of formaldehyde in the Antarctic atmosphere, Phys. Chem. Chem. Phys., 1, 5523-5527, 1999.

Sattler, B., Puxbaum, H., and Psenner, R.: Bacterial growth in supercooled could droplets, Geophys. Res. Lett., 28, 239-242, 2001.

Satsumabayashi, H., Kurita, H., Chang, Y.-S., Carmichael, G. R., and Ueda, H.: Photochemical formations of lower aldehydes and lower fatty acids under long-range transport in central Japan, Atmos. Environ., 29, 255-266, 1995.

Sellegri, K., Laj, P., Marinoni, A., Dupuy, R., Legrand, M., and Preunkert, S.: Contribution of gaseous and particulate species to droplet solute composition at the Puy de Dôme, France, Atmos. 
Chem. Phys., 3, 1509-1522, 2003,

http://www.atmos-chem-phys.net/3/1509/2003/.

Suzuki, Y., Imai, S., Kawakami, M., Masuda, K., and Akasaka, K.: Identification and determination of low-molecular weight organic compounds in contaminated fog water using proton nuclear magnetic resonance spectroscopy, Bull. Environ. Contam. Toxicol., 60, 355-362, 1998.

Van Pinxteren, D., Plewka, A., Hofmann, D., Müller, K., Kramberger, H., Svrcina, B., Bächmann, K., Jaeschke, W., Mertes, S., Collett Jr., J. L., and Herrmann, H.: Schmücke hill cap cloud and valley stations aerosol characterisation during FEBUKO (II): organic compounds, Atmos. Environ., 39, 4305-4320, 2005.
Voisin, D., Legrand, M., and Chaumerliac, N.: Scavenging of acidic gases $\left(\mathrm{HCOOH}, \mathrm{CH}_{3} \mathrm{COOH}, \mathrm{HNO}_{3}, \mathrm{HCl}\right.$ and $\left.\mathrm{SO}_{2}\right)$ and ammonia in mixed liquid-solid water clouds at the Puy de Dôme mountain (France), J. Geophys. Res., 105, 6817-6835, 2000.

Vorholt, J. A.: Cofactor-dependent pathways of formaldehyde oxidation in methylotrophic bacteria, Arch. Microbiol., 178, 239249, 2002. 